\title{
Analysis Of Factors That Influence The Allocated Time To Finish Thesis Of High Capability Students With CHAID Methods In Faculty Of Teacher's Training IAIN Bukittinggi
}

\author{
Haida Fitri ${ }^{1}$, Aniswita ${ }^{2}$, Charles $^{3}$, Merry Prima Dewi ${ }^{4}$ \\ \{haidanabibi@gmail.com¹, aniswitaumar@gmail.com², charlesmalinkayo.cc@gmail.com³, \\ merryprimadewi@gmail.com ${ }^{4}$ \} \\ Mathematics Education Department, Institut Agama Islam Negeri (IAIN) Bukittinggi, Indonesia ${ }^{1,2}$ \\ Islamic Studies Department, Institut Agama Islam Negeri (IAIN) Bukittinggi, Indonesia ${ }^{3}$ \\ English Department, Institut Agama Islam Negeri (IAIN) Bukittinggi, Indonesia ${ }^{4}$
}

\begin{abstract}
Thesis is one of the requirements that must be fulfilled by students to complete the bachelors program (S1). Ideally the thesis can be completed in six months, but in fact many students who completed it exceeded the ideal time, including students who have a GPA above 3.51 (high category). 51\% of graduates from Faculty of Teacher's Training (FTIK) IAIN Bukittinggi who belongs to the high capability delays in completing their thesis. Many factors affect the delay both internally and externally. To see what factors significantly influence the researchers used the CHAID Methods. This method is superior compared to other methods because the analysis is faster and the data is presented in the form of tree diagrams, making it more interesting and easier to translate. Based on the analysis of CHAID, it was obtained that the significant factors influence the length of time to finish thesis; they are department and data sources. Characteristics of students who are likely to be late in completing their thesis are students from Islamic studies department or Counseling department and students from English department or mathematics department or informatics and computer engineering department with secondary data sources. The analytical accuracy of the resulting model is $80.6 \%$. These results are supposed to be one of the references to minimize time delays in completing the thesis for high capability students in Faculty of Teacher's Training IAIN Bukittinggi.
\end{abstract}

Keywords. analysis, thesis, allocated time to finish thesis, GPA, CHAID method.

\section{Introduction}

Research is an important component in the development of science and technology. This is in accordance with one of the goals of higher education which is to produce science and technology through research that pays attention to and applies the value of the humanities to benefit the progress of the nation, as well as the progress of civilization and human well-being [1]. To accelerate the expansion of knowledge, results of research must be published. This is the reason that students must have the ability to write, especially in academic contexts or academic writing. One form of academic writing that is charged to students to complete the Strata 1 program is a thesis. Thesis is a scientific research that is written based on the results of 
field research or library research and is defended in front of the examination session in order to complete the undergraduate study (S1) to obtain a bachelor's degree[2]. Thesis is charged to students with the requirements that are regulated and stipulated in the curriculum of study programs and in accordance with the academic rules of higher education. Ideally, the thesis will be completed in six months or one semester[3].

The process of completing a thesis becomes a challenge for students, quite a lot of students are experiencing problems so that the completion of the thesis is not in accordance with the time it should be. According to Mage and Priyowidodo in Akbar, preparing a thesis for some students is a scary thing that must be done, because for some people writing a thesis is considered a very heavy job[4]. According to Agnes Maria Polina and Jong Jek Siang, there are two factors that influence the completion of a longer thesis, i.e.

a. Internal factors.

Two main causes that become internal factors of students, including motivation and academic ability are quite low.

b. External factors.

External factors that can hinder the completion of the thesis are the difficulty of the material / title of the thesis being worked on, the difficulty of finding literature or data, problems with the supervisor, environmental factors and others. [5]

In line with some of result of relevant research about internal and external factors that influence the allocated time to finish thesis that is the sex of the main supervisor, GPA, the expertise of the main supervisor and the topic of the thesis [6]. other factors are students academic ability, cost, effectiveness of the thesis guidance process with supervisor, faculty academic policy [7]. Besides that, based on the result of research's Mabel Xander Natas Pasaribu et al in 2016 concluded that the internal factors are low motivation, self-suggestion that the thesis is a final project that is difficult to do, less confident with own abilities. For external factors are poor time management skills, difficulties in finding references, difficulties in the mechanism of guidance with supervisors and difficulty in expressing ideas in thesis writing [8]. Based on above explanation, academic ability is one of the internal factors that influence the completion of the thesis. Student academic abilities are illustrated by GPA. GPA is a number that shows student achievement from the first semester to the last semester [9]]. Learning achievement is the level of student achievement towards the goals set by each field of study after following the learning process [10]. Learning according to Hilgard and Brower in Baharuddin and Esa Nur Wahyuni, has the understanding of getting knowledge or mastering knowledge through experience, remembering, mastering experience, and getting information or discovering [11]. So the GPA is a number that shows the level of achievement of a student in terms of knowledge, experience and skills that have been determined by each field of study through experience, remembering, mastering experience, and getting information or discovering.

Based on Bukittinggi IAIN academic guidelines, the GPA obtained by students is categorized into three groups, they are category I: $3.51 \leq$ GPA $\leq 4.00$, category II: $2.76 \leq$ GPA $\leq 3.50$ and category III: $2.00 \leq$ GPA $\leq 2.75$. [12]. The GPA categories illustrate the level of ability of students, where category I for students with high ability, category II for students with medium ability and category three illustrates the ability of students who are low. The difference in ability or GPA certainly results in the completion of the thesis, where according to research results by Hazimatululfah et al, the higher the student's achievement the faster the student is able to complete the thesis. [13]]. So that High-ability students should be able to complete their thesis on time. 
The results of that research is contradiction with the data obtained by the author in the field, from 1537 people graduated from the Faculty of Teacher Training (FTIK) IAIN Bukittinggi there are 243 graduates who have high GPA, and 51\% completed their thesis longer than the ideal time. Based on interviews with several graduates, it is known that the obstacles they experience when working on their thesis are the difficulty of finding the right book references, less of understanding of the methods used in research, difficulties in data processing and difficulties in meeting with supervisor. Other obstacles related to the determination of the selected thesis title, even during the guidance process there are students who have to change the title.To find of the factors that influence the allocated time of finish thesis for the student with high GPA category and analysis the relationship of that factors, we need a statistical method. The statistical method used is the CHAID (Chi-Square Automatic Interaction Detection) method. CHAID was first introduced in an article entitled "An Exploratory Technique for Investigating Large Quantities of Categorical Data" by Dr. G.V. Kasst 1980. The procedure, an offshoot of an earlier technique known as Automatic Interaction Detection (AID), and uses the chi-square test as its main tool. The CHAID method generally works by studying the relationship between the dependent variable with several independent variables. CHAID is an iterative technique that tests one by one the independent variables used in classification, and arranges them based on the significance level of chi-square statistics on the dependent variable [14]. So CHAID chooses a significant independent variable that influences its dependent variable based on the chi quare test. Chi square test is a non-parametric test that does not require a prerequisite test and is suitable for testing the relationship between variables in the form of categories. Furthermore, the analysis of the CHAID method is presented in the form of a tree diagram, making it more interesting and easier to translate [15]. Based on the explanation above, the authors are interested to know the factors that influence the allocated time to finish thesis of high capability students with CHAID methods in Faculty of Teacher's Training (FTIK) in Bukittinggi and then analyze relations between these factors. The results of this research are supposed to be one of the references to minimize time delay in completing the thesis for high capability students in FTIK IAIN Bukittinggi.

\section{Research Method}

The research method used is descriptive research with a correlation study of factors that influence the allocated time to finish thesis. The place of this research is in the Faculty of Teacher Training (FTIK) IAIN Bukittinggi with a total of 243 graduates who have a GPA of 3.51-4.00 (high category). The variables in this research are the allocated time to finish thesis (MPS) as the dependent variable and the independent variables are eight with each its category. There are two categories of dependent variables of the allocated time to finish thesis, they are category I is less than or equal to 6 months (fast or on time) and category II is more than 6 months (slow). The type of that variable is ordinal. While description of independent variables is presented in the table 1 independent variables observed:

Table 1. Independent variables observed

\begin{tabular}{llll}
\hline No & Variable Name (Notation) & Type & \multicolumn{1}{c}{ Categori } \\
\hline 1 & Gender of the students & Nominal & 1: Male \\
& & & 2: Female \\
2 & Methods Research (JP) & Nominal & 1:Quantitative \\
& & & 2:Qualitative \\
& & & 3: Combined \\
& & & 4: Literature Study \\
\hline
\end{tabular}




\begin{tabular}{|c|c|c|c|}
\hline No & Variable Name (Notation) & Type & $\begin{array}{l}\text { Categori } \\
\text { 5: Development }\end{array}$ \\
\hline 3 & $\begin{array}{l}\text { Gender of the main or second } \\
\text { supervisor (JKDP1 or JKDP2) }\end{array}$ & NomiNal & $\begin{array}{l}\text { 1:Male } \\
2: \text { Female }\end{array}$ \\
\hline 4 & $\begin{array}{l}\text { Field of Expertise The main or } \\
\text { second supervisor (BKD } 1 \text { or } \\
\text { BKD 2) }\end{array}$ & Nominal & $\begin{array}{l}\text { 1:Expertise according to } \\
\text { department } \\
\text { 2: Relevant ecpertise with } \\
\text { department } \\
\text { 3: General Education } \\
\text { 4: etc }\end{array}$ \\
\hline 5 & Research Data Source (SD) & Nominal & $\begin{array}{l}\text { 1: Primary } \\
\text { 2: Secondary } \\
\text { 3: Combined } \\
\text { 4: etc }\end{array}$ \\
\hline 6 & $\begin{array}{l}\text { Data collection technique } \\
\text { (TPD) }\end{array}$ & Nominal & $\begin{array}{l}\text { 1:Test } \\
2: \text { Questionnaire } \\
\text { 3:Obesrvation or interview } \\
\text { 4: Combined } \\
5: \text { etc }\end{array}$ \\
\hline 7 & Department (PS) & Nominal & $\begin{array}{l}\text { 1: Islamic Studies Department } \\
\text { (PAI) } \\
\text { 2: Arabic Department (PBA) } \\
\text { 3: English Department (PBI) } \\
\text { 4: Mathematics Department } \\
\text { (PMTK) } \\
\text { 5: Informatics and Computer } \\
\text { Engineering (PTIK) }\end{array}$ \\
\hline & & & $\begin{array}{l}\text { 6: Counseling Department } \\
(\mathrm{BK})\end{array}$ \\
\hline
\end{tabular}

Data collection techniques used were documentation and questionnaires distributed to 243 alumni who had a high category GPA. The data obtained were analyzed using CHAID analysis. Below is the description of the CHAID algorithm.

Step 1. For each predictor (independent variable) cross tabulate between the predictor categories (independent variable) with the dependent variable categories and then do steps 2 and 3 .

Step 2. Find the pair of categories of predictors (consider combining categories according to the nature of each type of variable) whose $2 \times \mathrm{d}$ sub-table is least significantly different. If this significance does not reach a critical value, combine the two categories into a single category and repeat this step. This significant test uses the chi-square test.

Step 3. For each combined category consisting of three or more original categories, find the most significant binary split so that the combination can be broken down again. If the significance is beyond a critical value, implement the split and return to the second stage.

tep 4. Calculate the significance of each predictor combined optimally and select the most significant. If the significance value is greater than the critical value, then divide the data according to the categories (combined categories) of the chosen predictors

Step 5. For each partition of the data that has not yet been analyzed, return to first step. This step can be modified by excluding from further analysis partitions with a small number of observations.[14] 
The CHAID method calculation results are presented in the form of a tree diagram as in Figure 1. Tree Diagram in CHAID analysis. According to Myers in Yohanes Sondang Kunto et al, the tree diagram follows the rules from the top down. This tree diagram starts from the parent group then goes to the sub group (child node) and so on until the group there are no more branches which are also called terminal nodes. [16]

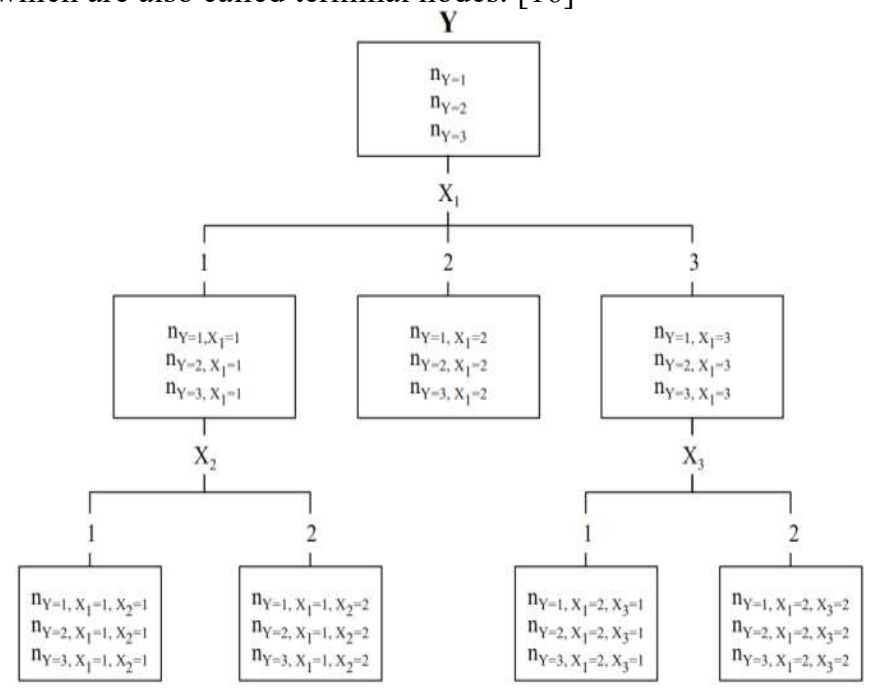

Fig 1. Tree Diagram of CHAID Analysis

\section{Result and Discussion}

The data obtained were analyzed using the stages in CHAID with the help of SPSS 22.0 software. The model used have the depth of the tree is 2 , the minimum cases in parent node is 70 and the minimum cases in child node is 30 . The results of the analysis show a significant factors that influence the allocated time of finish thesis are the department and research data sources. Number of Nodes obtained 6, Number of Terminal Nodes 4 and Depth are 2. For more details, the results of the CHAID analysis are presented in the tree diagram in Figure 2. Tree diagram of CHAID analysis of factors that influence the allocated time to finish thesis of high capability students.

The CHAID classification tree in Figure 2 describes the high-ability graduates of the IAIN Bukittinggi FTIK divided into four characteristics,i.e

- Characteristics 1: Graduates who come from PAI or BK department.

- Characteristics 2: Graduates who come from PBA department.

- Characteristics 3: Graduates who come from PBI or PMTK or PTIK department who use primary or combined data sources.

- Characteristics 4: Graduates who come from PBI or PMTK or PTIK department who use secondary data sources.

From the all of the characteristics of the graduates, there are 2 characteristics that are suspected of having greater opportunities to complete the thesis longer. These characteristics are FTIK graduates from PAI / BK department and FTIK graduates from PBI / PMTK / PTIK department who use secondary data sources. 


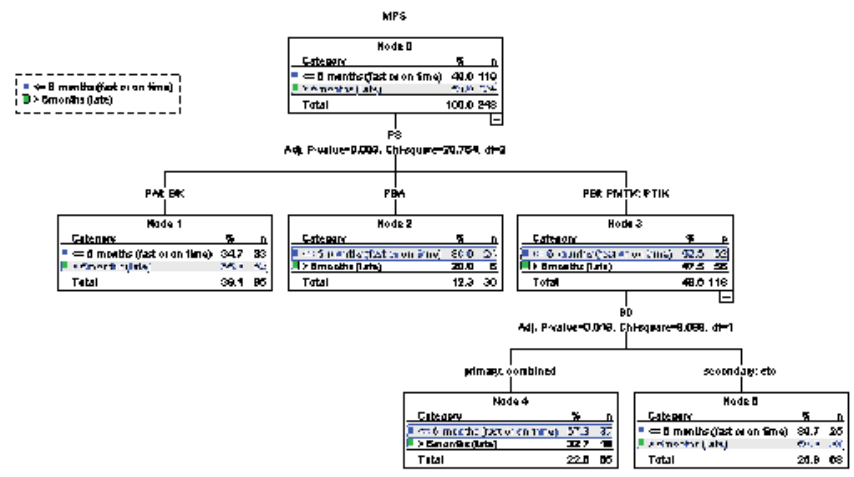

Fig 2. Tree Diagram of CHAID Analysis of Factors That Influence The Allocated Time to Finish Thesis of High Capability Students

The accuracy of the model produced by the CHAID analysis, overall is $66.3 \%$ with $51.3 \%$ to predict high capability students who are able to finish the thesis on time and $80.6 \%$ to predict which graduates are completing their thesis is over 6 months. So this model is very good in predicting the factors that affect the allocated time to complete the thesis more than 6 months. For more detailed and complete results of the accuracy of the models produced by the CHAID analysis can be seen in the following table 2 classification:

Table 2. Classification

\begin{tabular}{|l|c|c|c|}
\hline \multirow{2}{*}{ Observed } & \multicolumn{3}{|c|}{ Predicted } \\
\cline { 2 - 4 } & $\begin{array}{l}<=6 \text { months } \\
\text { (fast or on time) }\end{array}$ & $\begin{array}{l}>\mathbf{6} \text { months } \\
\text { (late) }\end{array}$ & Percent Correct \\
\hline $\begin{array}{l}<=6 \text { months } \\
\text { (fast or on time) }\end{array}$ & 61 & 58 & $51.3 \%$ \\
\hline$>6$ months (late) & 24 & 100 & $80.6 \%$ \\
\hline $\begin{array}{l}\text { Overall } \\
\text { Percentage }\end{array}$ & $35.0 \%$ & $65.0 \%$ & $66.3 \%$ \\
\hline
\end{tabular}

\section{Conclusion}

So that, students with high abilities also have their own obstacles in completing a thesis, so they have the opportunity to complete more than 6 months. Based on the analysis of CHAID methods there are 2 of 9 factors that influence the completion of the thesis, they are department and research data sources. There are 2 characteristics that are suspected of having a greater chance of late completing a thesis. These characteristics are FTIK graduates from PAI / BK department and FTIK graduates from PBI / PMTK / PTIK study programs who use secondary data sources. The prediction accuracy of the model produced by CHAID for this delay is $80.6 \%$. 


\section{Suggestions}

Suggestions for further research to look at the factors that influence the allocated time to finish thesis with more diverse variables such as student motivation, economic ability, majors from school and others.

\section{References}

[1] “UU RI No. 12 Tahun 2012 Tentang Pendidikan Tinggi.” pp. 57-77, 2012.

[2] Pedoman penulisan tugas akhir dan skripsi IAIN Bukittinggi. Bukittinggi: LPM IAIN BUKITTINGGI, 2015.

[3] KKNI IAIN Bukittinggi. Bukittinggi: LPM IAIN BUKITTINGGI, 2017.

[4] A. Akbar, "Hubungan Antara Kecerdasan Emosional Dengan Kecemasan Pada Mahasiswa STIKER Nani Hasanuddin Makasar Yang Sedang Menyusun Skripsi,” J. Ilm. Kesehat. Diagnosis, vol. 3, no. No 1, pp. 1-9, 2010.

[5] J. J. S. Agnes Maria Polina, Cara Cepat Menyusun Skripsi. Yogyakarta: Andi, 2009.

[6] D. C. S, S. Yohana, and P. B. J. Bangun, "FAKTOR RISIKO LAMA PENYELESAIAN SKRIPSI MAHASISWA ( Studi Kasus di Jurusan Matematika FMIPA Universitas Sriwijaya )," in Seminar Nasional Matematika dan pendidikan matematika dg tema "Penguatan Peran Matematika dan Pendidikan MAtematika untuk Indonesia yang lebih baik, 2013, vol. 94, no. September 2010, pp. 978-979.

[7] S. Hariyadi, A. Haris, F. Anto, and W. A. Sari, "Identifikasi Faktor-Faktor Yang Mempengaruhi Penyelesaian Skripsi Pada Mahasiswa S1 Psikologi Di Kota Semarang,” J. Penelit. PendidikanA A, vol. 34, no. 2, pp. 155-160, 2017.

[8] M. Xander, N. Pasaribu, and I. Syofii, "PADA MAHASISWA PROGRAM STUDI PENDIDIKAN TEKNIK MESIN UNIVERSTAS SRIWIJAYA,” J. Pendidik. Tek. Mesin, vol. 3, no. No 1, pp. 24-28, 2016.

[9] B. Salam, Cara Belajar Yang Sukses di Perguruan Tinggi. 2004.

[10] S. Arikunto, Prosedur Penelitian Suatu Pendekatan Praktik Jakarta. Jakarta: Rineka Cipta, 2006.

[11] B. and E. N. Wahyuni, Teori Belajar dan Pembelajaran ,. Yogyakarta: Ar-ruzz Media, 2010.

[12] Pedoman akademik IAIN Bukittinggi. 2015.

[13] E. C. Hazimatul Ulfah, Tri Kurniawati, "EcoGen EcoGen," EcoGen, vol. 1, no. 2016, pp. 955-966, 2018.

[14] C. A. Gallagher, H. M. Monroe, and J. L. Fish, "An Iterative Approach To Classification Analysis," 2000, pp. 237-280.

[15] G. M. Nisbet, Robert, John Elder, Handbook of statistical analysis and data mining applications [recurs electrònic] / Robert Nisbet, John Elder, Gary Miner. New York: Academik Press, 2009.

[16] S. N. H. Kunto, Yohanes Sondang, "ANALISIS CHAID SEBAGAI ALAT BANTU STATISTIKA UNTUK SEGMENTASI PASAR ( Studi Kasus pada Koperasi Syari' ah AlHidayah )," J. Manaj. Pemasar., vol. 1, no. No.2, pp. 88-98, 2006. 